\title{
Understanding the Platonic Dialogue from the Perspective of Gadamer's Hermeneutics
}

\author{
Chunge Liu \\ The School of Foreign Languages, Dalian University of Technology, China \\ Xiaodi Sui \\ The School of Foreign Languages, Dalian University of Technology, China
}

\begin{abstract}
This article focuses on Plato's The Republic from the perspective of Gadamer's hermeneutic understanding, which has three dimensions, that is, dialogue, effective history and hermeneutic circle. Firstly, the article introduces the general characteristics of the Platonic dialogue and Socrates' dialectic devices in The Republic. Then, it analyzes the Platonic dialogue in The Republic from the perspective of effective history. Historical and social elements are discussed, including Socrates's life, the democracy, the ancient Greek spirit and the sophism. Thirdly, the article explicates the Platonic dialogue in The Republic from the perspective of hermeneutic circle. The relationship of the totality and metaphysics of the Platonic philosophy and the individuality and concretization of the Platonic dialogue are discussed. Finally, the article concludes that the distinct characteristics of Platonic dialogue-being open, equal, sincere, emphasizing the dialogic process and self-understanding, applying Socrates' dialectics - are consistent with Socrates and Plato's pursuit of truth. Plato's choice of dialogue as the form of writing is influenced by Socrates, Athenian democracy, Greek spirit and sophism. And finally, the individuality and concretization of the Platonic dialogue and the totality and metaphysics of the Platonic philosophy are complements to each other. All these aspects follow the dialogue, effective history and hermeneutic circle in hermeneutic understanding.
\end{abstract}

Index Terms-Plato, dialogue, Hans-Georg Gadamer, hermeneutics

\section{Introduction: The Platonic Dialogue}

Plato takes dialogue as the form of The Republic, and meanwhile Gadamer discusses the characteristics of dialogue from the perspective of hermeneutic understanding. From the perspective of Gadamer's hermeneutics, dialogue creates openness, equality and sincerity between the participants. Dialogue does not emphasize an closed ending of statment. It is the dialogic process that matters most. What's more, hermeneutic understanding pays attention to self-understanding. The Platonic dialogue has the general characteristics of hermeneutic dialogue mentioned above. Besides, Socratic dialectic devices of cross-examination, irony and midwifery provide methods for the Philosophical inquiry and discovery of truth and reality.

Dialogue is an event in process, which aims for meaning and truth. Dialogue, according to Gadamer, is "the model for philosophical conversation" and it is carried out by "emergence of the question" and "letting meaning emerge in an 'event' of mutual understanding" (Michelfelder \& Palmer, 1989, pp.1-6). In dialogue, participants view themselves as "conversational partners, engaged in a joint search for meaning and truth" (Michelfelder \& Palmer, 1989, p. 6). More specifically, dialogue is conversation, communication and discussion. It involves at least two sides. To carry out a successful dialogue, participants must be fully engaged. They must be interested in the topic and try to understand the stance of the other participants and also give their own ideas. Dialogues have multiple levels in the hermeneutic understanding. It can take place within a text-between one part and another and also among different texts. It can take place between the past and the present and also among different social backgrounds. It can take place between the text and the readers and also among different readers. For example, when reading a text, people have to get the meaning of a sentence in a context — dialogue between one part and another within a text. People may also have to refer to other texts in order to fully understand the intention-dialogue between different texts. And moreover, people might need to know the social background of the author in order to acquire the deep meaning - dialogue between the past and the present. And people need to know how they really think of the text - dialogue between the text and the reader. Sometimes people need to know how others evaluate the text — dialogue between different readers. And also people need to know the backgrounds of other readers - dialogue among different social backgrounds. The process of understanding a certain text is the constant conversation between different factors mentioned above. And what people get in the end is the combination of all these factors. Based on hermeneutic understanding, the following characteristics of dialogue can be drawn.

\section{The Platonic Dialogue from the Perspective of Gadamer’s Dialogue}


According to Gadamer, dialogue is an event of openness, equality and sincerity. There are two aspects concerning openness. Firstly, participants engaged in a discussion must give their own opinions and their real thought about a topic. They must open their mind to others. This willingness of participation is the premise of a dialogue. They have to get someone know what they think and why they think it in that way. If one side of a dialogue does not give their opinion, it will turn out to be a monologue, whose essence is quite different. Secondly, they must allow others to give opinions. A dialogue allows no hegemony. The right to speak belongs to all participants. Ideas may be different but there is no such opinion that is absolutely right and all the participants have to accept nor such idea that is absolutely wrong and must be condemned. The value of dialogue is to listen to different ideas and think about how can improve the opinions about a topic towards a better one. There is no best solution, just better ones. And the process of getting to a better solution requires participants to be open. Equality and sincerity can be two other statements of openness. These three aspects share the same essence as described above - the full participation of both sides in the discussion. The nature of dialogue is equal communication, mutual exploration and understanding improvement. It breaks the barriers of authority and creates a free space with open atmosphere. The openness, equality and sincerity can bring out the primitive thoughts of the participants without many scruples.

Gadamer takes dialogue from the perspective of the hermeneutic understanding as a constant conversation, discussion and communication among different participants - both within and outside a text. If people want to get a full understanding, they must approach it with the attitude of openness, sincerity and equality. What really counts is the process of dialogue instead of the conclusion and everyone can improve his or her own understanding towards self and the world. Also, Gadamer takes the Platonic dialogues as the illustration of his understanding of dialogue. The Platonic dialogue is characterized with openness, equality, and sincerity. What's more, the Platonic dialogue attaches great importance to the process rather than the conclusion and at last, self-understanding in this process is also highlighted.

The Platonic dialogue of Socrates is characterized with the sense of openness, equality and sincerity, which leads to participants' endeavor for understanding truth. In the ancient Athenian state, Socrates was greatly welcomed by the young who were in great hunger for knowledge. One of the reasons is the way he talked with other people. Unlike the discussions with sophists who were so overwhelming that other participants seemed to be intimidated, dialogues with Socrates were always under an atmosphere of openness, equality and sincerity. In The Republic, Socrates gives chance to whoever wants to speak their mind. For example, when talking about what is justice, Cephalus, Polemarchus, Thrasymachus, Glaucon and Adeimantus give their opinions one after another. Socrates gives his opinions and refutations one by one. Although not every participant is so polite, Socrates is quite competent in putting the overall situation under control and makes sure that it is open, equal and sincere. One participant who is also a sophist, Thrasymachus, seems to be so confident in his arguments that he "often tried to interrupt" and seems to "burst out" and often "laughed sarcastically" (Lee, 1987, p. 17). However, Socrates always tries to answer him politely "if we have made any mistake in our consideration of the argument, I assure you we have not done so on purpose" and "That's because you're so clever, Thrasymachus" (Lee, 1987, p. 17). Anyway, a good atmosphere is the premise for the successful proceeding of dialogue. Although it is not the main topic under concern, it gives the participants the feeling of openness, equality and sincerity. No matter what the reaction of other participants towards his opinions, Socrates seems to be so charismatic that he can always bring them to such open atmosphere which can encourage them to air their views. The openness, equality and sincerity are main characteristics of the Platonic dialogue and what Socrates really wants is the full engagement of the participants in the discovery and inquiry of truth and reality.

The purpose of The Republic and the other Platonic dialogues is the change of Athenian ethical order, which demands a discussion instead of an ending statement. What is on Socrates' mind is how to improve the interlocutors' understanding towards major moral issues rather than tell them what they should do. He is fully aware that doctrines and conclusions have little effect on people's souls. Their dogmatic opinions or traditional ideas must be changed little by little and only by the careful examination of each bit of their thought can they change what has long been held, drawing insights from the dialogue. The careful examination is the process. In discussing about what is justice, Socrates listens carefully to his interlocutors' opinions, analyzes with them and tells what's wrong with their opinion. But he does not give his definition about what is justice. Although later in The Republic, readers can draw the Socratic idea that justice is the PS or Principle of Specialization (Waterfield, 2008, p. 76) which means that each one does what is most appropriate for him to do, such an idea is arrived through lots of discussions and it is reached naturally. It is the process towards such a conclusion that counts most, because the process of dialogue also reflects the process of thinking, thus, dialogues with Socrates become good practice of thinking - another goal of Platonic dialogue. Therefore, people can see that Platonic dialogue emphasizes the process instead of conclusion.

The Platonic dialogue aims for knowledge which is realized through dialogic communication instead of teaching. Socrates loves knowledge. But in his mind, knowledge cannot be taught. He thinks that what he can do is to lead his interlocutors towards knowledge. As different people hold different opinions, the improvement of their understanding can also be different. Again, when talking about what is justice, Cephalus and Thrasymachus harbor different ideas. Socrates gives them different instructions, whether they accept or not or to what extent do they understand Socrates' ideas determine how much improvement they can make. What's more, the process of giving their opinions and trying to make others understand them is also the process of self-persuasion. Ideas in the mind are not as clear as when they are spoken out. In exchanging ideas with others, Socrates, as well as other interlocutors can have a better understanding 
what is really on their mind and whether it can persuade themselves in the first place. So, either by trying to understand others or trying to make their own ideas clear, Platonic dialogue is helpful to the participants for their self-understanding and self-improvement.

From the perspective of hermeneutics, the main characteristic of the Republic and the other Platonic dialogues is their enventfulness. Generally, the Platonic dialogue in The Republic shares the general characteristics of dialogue in hermeneutic understanding. Platonic dialogue is proceeding under an atmosphere of openness, equality and sincerity. It also puts an emphasis on the process rather than the conclusion since in Plato's mind, there is no doctrine. What one gets at last is better self-understanding and self-improvement. Those characteristics are attributable to Socratic idea that one should never end his pursuit of knowledge.

For the sake of denying the uncertainty of Sophists' technical application of dialogue as sophistry, Plato develops the dialectic dialogue. In the modern sense, dialectic has multiple meanings. It can be Marxist material dialectic. It can be Hegel's dialectic. And it can also be sophist, Socrates' and Plato's dialectics. The later ones (Marxist and Hegel's) are the development of the previous ones (Socrates' and Plato's). However, it should be interpreted in a more basic sense - the sophist dialectic. The early interpretation of dialectic is more or less like rhetoric or the art of debate. Rhetoric in the ancient Greek was the art or technique to debate. By the $5^{\text {th }}$ century, rhetoric had become a special knowledge and there were people who taught rhetoric and the technique needed in public speaking. They taught people how to use language and how to argue in order to win. Therefore, in the original sense, dialectics means the art to argue and the main purpose is to defeat the opponent and win out. That is the main idea of the sophist dialectic or sophistry (Zhu \& Fang, 2002, p. 211). The sophist dialectic is more a persuasion than an inquiry and a discovery of truth. Socrates dislikes the method of argument for win's sake. He concentrates more on the collaboration and reasoning process with the interlocutors for the inquiry and discovery of truth (Kidder, 1997, p. 55). In this sense, the Socratic dialectic is more like a dialogue, the way of discussion by question - answer process. Socrates used three main dialectic devices in The Republic - cross-examination, irony and midwifery (Hu, 2009, p. 27).

Cross-examination is the pattern in The Republic, which confines the uncertainty and ambiguity of the meaning in participants' conversation.Cross-examination of the Platonic dialogue in The Republic is to question closely and eagerly. It forces responders to think deeply and to try to clear away any ambiguity. Sometimes, ideas people have are from either common sense or hearsays that they usually don't doubt or just take for granted. By cross-examination, nothing is so certain and no concept is so absolute that are beyond doubt. It can help the dialogue participants-both the questioners and the responders, cultivate a spirit of query. Cross-examination is a kind of technique that the interlocutors can always take to their daily life. Not only the topic is questioned, but also other ideas which are so familiar and "right" can be under suspicion. Cross-examination is such an effective way that it conforms perfectly to the Platonic philosophy — never-ending pursuit of truth. In The Republic, Socrates asks one question after another until his interlocutors have nothing to say and have to turn to Socrates to make things clear or give up their previous ideas.

Socrates applies irony as a constant dialectic device to the guidance of the participant's understanding of knowledge. Irony is a dialectic device used by Socrates in The Republic, which means that opposite ideas are not refuted at first, but affirmed, however, with the discussion going on, the interlocutors will notice the absurdness of their previous thought that they have to doubt it and negate it. Socrates is quite modest and he always appears as an ignorant person. He will praise the sophists for their "extensive information and learning". He encourages them to give their "wise opinion" concerning a topic and he will somewhat agree with them. Later, by discussion, the "wise people" will find the irrationality in their argument. Maybe at first, Socrates knows something wrong in the argument of his interlocutors, but he does not deny their ideas directly or instantly but give them positive responses. The initial agreement helps to create a friendly atmosphere in the first place and also shows sincerity, because it indicates that participants of dialogue are on the same boat and they want to go ahead together. The dialogue participants can dig deeper into the topic without much enmity or aversion in the first place. After all, the main purpose of the dialogue or Socrates inquiry is to arouse people's interest and attention to think deep about the condition and purpose of their life and their souls.

Socrates also applies midwifery for the purpose of helping the participant to realize the truth. Midwifery is the third dialectic device that is commonly used by Socrates in The Republic. Midwifery has two layers, the physiological one and the spiritual one (Hu, 2009, p. 66). And the Socratic midwifery is the spiritual one. In discussions with his interlocutors, Socrates would destroy some common sense or proposition which was held by people as standards in life and ethics. The Socratic dialectic made people realize that what they believed was not so reliable and even contradictory and absurd. His dialectic is to trigger new thoughts and new ideas. After the negation of the interlocutors' previous ideas, he will lead them to new ones. However, to say that it is midwifery is due to the fact that Socrates does not give any certain conclusion to a topic. He just acts as a guide or a midwife. The generation of any idea is due to every individual himself. The discussion with Socrates may be floundering and struggling in the interlocutors' mind and soul, but they get closer to truth and reality. They are making progress towards knowledge.

The Socratic dialectic in the dialogue represents Socrates's understanding of the process of attaining knowledge. The Socratic dialectic is the question-answer process of dialogue. The cross-examination, irony and midwifery are the main dialectic devices in carrying out the Socratic and Platonic philosophical inquiry and discovery. Unlike the sophist dialectic whose aim is to win an argument without paying attention to reality and truth, the Socratic dialectic is to focus on the more reasonable and the truer. It leads people away from opinion and to knowledge. To Socrates, an unexamined 
life is one unworthy to be lived. What is always on his mind is how should one live. He would not tell his interlocutors the answers to these big questions, but invite them to discover the answers with him. By using the dialectic devices - cross-examination, irony and midwifery, he helps purify the souls of the Athenians and get rid of innocence, at the same time, developing the dialogue.

\section{The Platonic Dialogue from the Perspective of GadameR’s Effective History}

Gadamer's effective history demands historical understanding of Plato's The Republic. Effective history reminds people that writers of texts they encounter are also influenced by certain historical and cultural backgrounds. The way they write, the form they choose, the content they cover, and the techniques they use are all results of that particular background. Therefore, when people approach a text, it is helpful for them to know the historical and cultural environment of the writer and also the background of the text. Historicism should not only concentrate on the works that have been passed down, but also notice the effect of phenomenon in history (Gadamer, 2007, p. 223). Take The Republic for example. Plato's application of dialogue as the form to convey his philosophical thought is greatly influenced by the historical and cultural environment he was in, by his respected teacher Socrates, by the democratic environment and the Greek spirit and by the sophist abuse of rhetoric.

Gadamer's effective history reveals that Plato's The Republic cannot be cut away from the past and the tradition. Effective history is to understand the present from the perspective of the past. People' consciousness is determined by the effective history which embodies the whole strength of tradition. People can never break away from it and the effective history extends and also limits their way of thinking. It provides the background of all their values. Writers of texts are influenced by the tradition they are in and an understanding of this tradition can help readers better understand the texts they are reading.

The written language is out of the authorial control, so Socrates absolutely denies it. Socrates himself dislikes written language. He spent all his life in the high streets and back lanes, discussing issues concerning morals, politics and philosophy. He would confront anyone who he met and who acclaimed to harbor extensive information and learning. However, Socrates himself never wrote. Actually the images readers get about him are mostly through Plato's description. Socrates is the faithful defender of oral conversation and he dislikes writing. Plato, in the Phaedrus, explained the famous Socratic indictment of writing. Firstly, writing cannot help improve memory as many may imagine it to be. On the contrary, it sows the seed of forgetfulness. Once people can get the material they want, they are not willing to put it in their mind. For example, with the invention of e-dictionary, students would not like to remember English words because they can always turn to the e-dictionary. Anyway, the process of memorizing something wants effort and understanding. Writing is such a way of increasing forgetfulness and laziness of the mind that it goes against the Socratic philosophy that people should go on constant inquiry and discovery of truth and reality by thinking deep about themselves and the world they live in. Secondly, writing treatise is not a safe way to preserve one's thought. Treatises passed down may be misinterpreted and distorted by later incompetent readers. The original messages might be misused for bad purposes. Although nowadays some scholars encourage different interpretations of the same text, there should also be certain standards that each interpreter should follow; otherwise, the meaning of the text will be completely ruined. However, in Socrates' mind, it was rather risky to take such an adventure as he was not willing to set a standard for others to follow. He might have thought that the safest way is to keep the ideas in mind and improve them constantly rather than set them down. Thirdly, Socrates believed that words written down are dead. They could not communicate with others. And in most circumstances, it is just a one-way communication that makes readers rely on them. When the readers have some questions, it can not answer or give any active responses. To Socrates, the mutual communication is the most important because it is more lively and open. It removes the barriers between the participants and confronts their souls directly. By carrying out dialogues, Socrates strikes the souls of his interlocutors and brings vitality and vigor to them. Therefore, the written form is dead and closed while the dialogues and conversations are living and open.

For the sake of philosophical truth, Socrates relies on spoken language in the form of dialogue. To Socrates, the philosophical inquiry in the form of conversation is part of his life. He found the oral conversation is perfect for his goals and disliked writing. As a student, Plato respected and was influenced by Socrates. Socrates' dislike for writing must have played an important role in Plato's application of dialogue to convey his philosophical thought. Oral conversation is best for exploring truth and spreading thought. But it is instant and short-lived. Dialogue is the combination of oral conversation and writing and it fits the discovery and inquiry of truth and reality.

The Athenian democratic institution is the political realization of the Platonic dialogues. The democracy in the Athenian state plays a significant role in the emergence and development of the Platonic dialogue. From the dialogues people can see the charisma of ancient Greek culture and how people lived at that time. One important characteristic of the ancient Greek culture is the democratic environment, which had also nurtured the personality and temperament of the ancient Greek people - openness, equality, pursuit of truth and tolerance. The emergence of the dialogic form lies in the democratic environment. The Greeks had great enthusiasm in taking part in the public affairs. They had formed the habit of discussion and argument. They would not accept the ideas of others easily, but doubted and argued against them until they reached the truth. Their daily conversations were dialogues and what Plato did, to some extent, is to transfer them to the paper. The development of dialogue is mainly due to two aspects. 
The Athenian democracy provided the citizens with dialectic freedom. The Athenians had large public space, including municipal administrative buildings, such as the general assembly, court, and congress hall; religious buildings, such as temples, altars and public cemeteries; and places of social and cultural activities, such as theaters, stadiums and playgrounds. The Athens' political affairs were open to all the citizens. Every citizen had the right and obligation to take part in the state affairs and gave their opinions. Actually, the state affairs were part of their own life. All the important issues were decided by the general assembly where anyone who had capability and competence would stand out. The administrative power lay in the hands of citizens. Religious life was just as important. All the citizens were required to take part in the public sacrificial ceremony. They shared the blessing given by gods and gave sacrifices to gods. After the ceremony, they should dine together. The activity was so serious and important that those who did not participate would be deprived of citizenship. The sports and cultural activities were also open to all the citizens. From the fact that the ancient Olympic Games originated in the Athens in 776BC can readers get a glimpse of their love for sports. Amphitheaters put dramas on stage. The government encouraged people to go to the theaters by increasing the number of theaters and giving allowances to the poor. Citizens were free to give comments to the plays. From these aspects readers can see that the public places provided a platform for more open dialogues and communications. With all these public places, people had more opportunity to meet each other and discuss with each other. Their ideas can be exchanged quickly and instantly. More importantly, they were not constrained to talk about plays in the theatre, nor were they confined to talk about religion in temples. They could exchange ideas about politics or morals in theatres or other public places. It is just a matter of when they can meet, and what they want to talk about. The citizens opened their heart and talked about what was on their minds. At the same time, they were open to the opinions of others. Their awareness of equality among different citizens and tolerance of different opinions were enhanced with their spirit of pursuing truth and reality. Democracy promoted dialogues and dialogues also improved democracy.

The openness was embodied in the Athenian democracy, which led to the dialogic possibility. The ancient Athenians think highly of the communication with the outside world. A lot of contemporary playwrights, philosophers and writers traveled to other states. Although Socrates had seldom been out of Athens, he encouraged his students to go out. Plato had been to many places, such as Syracuse, Egypt and Italy and so on. Communications with the outside world opened their mind and horizon and through the overseas experiences, the Athenians understood that there were other customs, faiths and values. They became more tolerant and open towards different ideas and opinions. At the same time, a lot of scholars were attracted to Athens for its democratic environment. Indeed, Athens had become a hub of intellectuals with different backgrounds which also made dialogue possible.

The Athenian democracy allowed the pursuit of truth and reality. The emergence and development of dialogue is partly due to the democratic environment of the Athenian state and the open, equal and tolerant spirits of the Greek people for the pursuit of truth and reality. In turn, the dialogues and conversations of the Greek people had also increased the democracy and enhanced their awareness of the spirits of openness, equality, tolerance and pursuit of truth.

The Sophists in the Athenian society, who did not care about the certainty of truth, were another factor leading to the Platonic dialogue. Sophism is another factor that triggered the emergence and development of the Platonic dialogue. The democratic environment enabled more people to take part in the administration of the state. Since all the state affairs were decided by the general assembly, the ability to persuade people to one's own way of thinking and to win out in the general assembly was definitely instrumental to one's political life. One of the famous politicians, Pericles, successfully persuaded the Athenians to participate in the Peloponnesian war when he made the speech on the Memorial Day (Zhu \& Fang, 2002, p. 34). Rhetoric was so powerful that it was in great popularity at that time.

The sophists took dialogue as the form of rhetoric for the sake of the winning of the argument. The sophists earned money by teaching rhetoric in the state and their aim was quite explicit, that is to teach their students how to win in a debate. They made use of many skills in persuading the audience. Sometimes they gave harangues to make the audience so tired that had to agree with them. Sometimes they used sweet words in order to flatter people. Sometimes they even frightened people to agree with them. Besides, the sophists played with words and concepts. They usually didn't care about the fact and their ideas were based on phenomena and opinions. What they concentrated on is the language itself rather than reality. They relied on their senses and made them the standards of judgment. They believed that everything had two contradictory aspects and each aspect can be made reasonable as long as you acquired rhetoric. For example, one thing is big to person A, but may be small to person B as A and B may have different standards of judgment. Instead of giving the truth about bigness or smallness, the sophist rhetoric is how to make the weak points strong as they wish to. Whether the thing is really big or small is not the concern of the sophists. What counts most is how they could persuade others to believe that it is big or small. Maybe for the same thing, they could believe that it is big at one time and then small at another time. It is completely due to how they used rhetoric and they did not care about truth or reality at all. Socrates and Plato distasted this kind of argument. They thought that if one did not know the fact, how one could persuade others.

Although both the sophists and Socrates applied dialogue, the latter gave it dialectic truth, while the former uncertainty. The main differences between sophist rhetoric and Platonic dialogue are as follows. Firstly, sophists aimed at wealth, fame and power in their debate. They could make use of every trick in order to persuade others to their way of thinking. Their selfish purpose blinded their minds as well as others. The Platonic dialogue is to lead people to truth 
and reality. Its main purpose is to enlighten people's souls. Secondly, the sophists argued against different ideas for most of the time. They viewed people with different ideas as enemies and they tried their best to negate the others' ideas. The Platonic dialogue is a conversation and discussion. Everyone can have their own ideas and participants in a dialogue are cooperative towards the truth and reality. The atmosphere is friendly and results are more constructive rather than uncompromising. Thirdly, the sophists usually addressed to the public. They made long speeches and allowed no room for questions and personal thinking. They asserted that they had knowledge and all the listeners had to do was nothing but follow their ideas. In the Platonic dialogue, however, Socrates prefers to discuss with one interlocutor. Although there are lots of people around, readers can still notice that he meets the challenges one by one. His questions and rhetorical questions are one-person-targeted. By carrying out dialogues, Socrates confronted with individual soul directly ( $\mathrm{Hu}, 2009$, p. 96).

The Platonic dialogue from the perspective of effective history is a form of dialectics. The Platonic dialogue in The Republic can be understood from the perspective of effective history. It is generally accepted that the emergence and development of the Platonic dialogue have its deep root in the tradition in which Plato lived. Socrates' distaste for written language and preference for oral conversation made Plato combined the advantages of the two forms. The Athenian democracy and the Greek spirit guaranteed the possibility of everyday conversation and communication in Athens, which are lively sources of the Platonic dialogue. Plato was in an age when the sophism was in the heyday. Plato saw its negative effects on people's souls and set out on a new road by using dialogue as the form for his philosophical discovery. Next, the hermeneutic circle between the Platonic philosophy and the Platonic dialogue will be explicated.

\section{The Platonic Dialogue from the Perspective of Gadamer’s Hermeneutic Circle}

The movement of the hermeneutic circle resides in the fact that the parts of a particular symbolic context can be understood only through their significance for the whole, yet this whole is capable of being disclosed to the readers only through the significance of its parts. Gadamer maintains that the hermeneutic circle is neither subjective nor objective, but it is the interaction and mutual effects between the text and the interpreter (Tietz, 2010, p. 78). He used the hermeneutic circle to explain the circular relation between the understanding and tradition. The tradition is something passed down from the past and people' understanding is influenced by this tradition. The new understanding also serves as a tradition for future interpretations. This circle is constantly going on and on. The analysis of Plato's philosophical thought and dialogic form is based on a more basic sense - the whole and the parts.

The Platonic dialogue achieves the tension between the Platonic absolute and the Platonic individuality. In The Republic, the Platonic philosophy emphasizes totality while the Platonic dialogue focuses on individuality. Totality means self-sufficiency or self-containment. Totality separates one concept from another in the mind and enables them to be distinctive from existence. It is a system of specific qualities and features that delimit a certain concept and it is also a finite system which comes into being when all the separate and varied parts within this system play their roles. Carl Einstein assumes that "Totality means that the goal of all knowledge and endeavor no longer lies in the infinite, as an indefinable overall purpose, rather it is resolved in the singular, because totality justifies the concrete being of individual systems, endowing them with meaning" (p. 65). Individuality, however, is self-awareness. It stresses uniqueness and independence which indicate one's own goals and purposes. Individuality cares the interest of the single person and strives to address the individual problem. In The Republic, Plato constructs his ideal state around two major topics: what is justice and whether justice is rewarding. With the continuing of the dialogue, other aspects regarding politics, education and psychology etc. are also discussed. The Platonic philosophy can be summarized as an inquiry to what kind of life should man live and what is the greatest happiness. In designing his ideal state, Plato keeps his eyes on the whole and his ideal state is to achieve the justice and happiness of the whole. But the dialogic form concentrates more on the one-to-one discussion. The totality of Platonic philosophy should be understood through the individuality of the Platonic dialogue and the individuality of Platonic dialogue should be interpreted by understanding the totality of the philosophical thought.

In the Platonic dialogue, the process of understanding is characterized by the tension between certainty and uncertainty, and between the whole and parts. In designing his ideal state, Plato cares more about the unity, happiness and justice of the whole and pays little attention to the happiness of the individual factors in the state. However, the dialogic form concentrates on addressing individuals. If readers assume that there is some weakness in Plato's indifference to the individual happiness in the state, then the dialogic form is a good compromise. What's more, the whole of the Platonic philosophy acts as a guidance which leads the dialogue to move on smoothly. In order to get a satisfactory understanding of the Platonic philosophy, it is better for the readers to dig deep into the individuality of the Platonic dialogue. In order to have a better understanding of the Platonic dialogue, the totality of Platonic philosophy is better to keep in mind. The process of understanding is always from the parts to the whole and from the whole to the parts, thus fulfilling the hermeneutic circle.

The Form in the Platonic metaphysics is abstract, which demands the concrete realization. Plato's ideas of Form are quite metaphysical. The abstraction of the idea of Form is partly due to its basic characteristics. Zhu Qinghua and Fang Zhaohui assume that the Form has the following characteristics. Firstly, Form is eternal and can not be created or destroyed. Secondly, it can not be perceived by senses, but only by thought. Thirdly, only the Forms and the world of 
Forms are real. The sensible world is just like reflections in the river. Fourthly, every kind of things has a type of Form (Zhu \& Fang, 2002, p. 77).

The Platonic Form has three dimensions. According to Plato, Forms have three definitions (Zhu \& Fang, 2002, p. 79). In the first place, Forms have an ontological definition. Plato comes up with the "theory of participation" and "the theory of imitation." In the theory of participation, things are the way they are because they share the Form which is the origin of the kind of things. Plato gives the same kind of things a shared name because they share the Form. In the theory of imitation, the things are what they are because they imitate the Form. The Form is the prototype, the father; while the sensible things are copy, the children. What the same kind of things has is the surname-the Form. In the second place, Forms also have a teleological definition. The Form of everything is perfect, holy and eternal. Sensible things pursue their Forms. The nearer they are, the better they are. And the Forms also have their goal, which is the Form of goodness - the highest Form. So the world of Forms is hierarchical and the Form of goodness is the ultimate aim. Furthermore, Forms have a logical definition. The world of Forms is in a clear order and logic. However, the sensible world is in a chaos.

Although the Form is abstract, it demands concretization in things themselves. Another idea which also seems to be abstract is that Forms are things themselves. For example, something is beautiful because it shares beauty itself; something is big because it shares bigness itself; something is good because it shares goodness itself. The "itself" is actually the Form. More characteristics of Forms are as follows. They are absolute. They cannot be both beautiful and ugly, bother big and small. They are independent. They are not in the disguise of a book, nor a hand. They do not exist in a human being, nor do they exist on the earth or in the heaven. All in all, Forms are superior to all things and decide all things. In Platonic philosophy, Forms and the world of Forms truly exist and they serve as answers to all phenomena — natural phenomena, philosophical ones and human beings.

The problem of the paradox between the abstract Form and concrete things demands the form of dialogue. For all the characteristics and explanations given above, the idea of Form and its functions are still so obscure and abstract for readers to understand. But people need not to worry, for there is another method for the interpretation of such abstract philosophy. Readers can approach it from the dialogic form which is concrete. In The Republic, Plato uses three allegories to make the ideas concrete. When talking about the Forms, Plato gives three allegories - the cave, the line and the sun. Plato distinguishes between two worlds - the intelligible world and the visible world. The visible world is imaginary and the intelligible world is real. The visible world is full of opinion while the intelligible world is filled with knowledge. The sun is the king of the visible world while goodness is the king of the intelligible world. In the allegory of the sun, he compares the Form of goodness to the sun. The status of the Form of goodness in the intelligible world is just like the position of the sun in the visible world. The sun gives life to all things on the planet, helps them grow and nourishes them. So does the Form of goodness in the intelligible world. What's more, according to Plato, the sun is son of Form of goodness, so the Form of goodness is the driving force of both the visible world and the intelligible world. In the allegory of line, Plato divides the two worlds into four levels. The first level includes reflections and images. The second level is humans, animals and natural objects or handmade objects. The third level includes objects of mathematics, such as numbers and shapes, and the fourth level is the Forms. The first level and the second level belong to the visible world while the third level and the fourth level belong to the intelligible world. The latter level is much clearer and more real than the former. And the Forms are the most real of the four levels. In the allegory of the cave, the process of coming out of the cave is also the process of becoming closer to the Form, to knowledge and to the highest principle - the Form of goodness. These three allegories have close relation to one another and they act as explanations to one another. By using these allegories, Plato makes his ideas regarding Forms more vivid and understandable.

The Platonic philosophy of the idea of Forms is abstract and hard for understanding, but the Platonic dialogue makes it more concrete by using three allegories. And both abstraction and concretization are ways to explore the truth and they work as complement for each other. Readers are in the hermeneutic circle by moving between the abstract and the concrete, which is also in accordance with the exploration of truth — constant back and forth, to and fro. To Plato, truth or the highest principle can not be demonstrated, but lies in constant exploring and inquiring.

From the perspective of the hermeneutic circle, the dialogic The Republic does achieve the abstract absolute. The hermeneutic circle in the hermeneutic understanding provides a perspective for the analysis of the Platonic dialogue in The Republic. The circular movement of the part and the whole can help readers better understand the relationship of the Platonic philosophy and the Platonic dialogue (here, refers to the dialogic form), discussed as followed, the totality of the Platonic philosophy and the individuality of the Platonic dialogue, the metaphysics of the Platonic philosophy and the concretization of the Platonic dialogue.

\section{CONCLUSION}

This article concludes that from the perspective Gadamer's hermeneutics, the Platonic dialogue is the realization of the Platonic truth in the tension between the absolute whole and individual parts. The Platonic dialogue in The Republic has the distinct characteristics of hermeneutic dialogue-being open, equal, and sincere, emphasizing the dialogic process and self-understanding. Besides, the Platonic dialogue applies Socrates' dialectics. These characteristics are in alignment with Socrates and Plato's pursuit of truth. The emergence and development of the Platonic dialogue have historical and social reasons, which are understood as effective history in the hermeneutic understanding. Plato was 
influenced by Socrates, the Athenian democracy, the Greek spirit and sophism. What's more, as two aspects of the Platonic dialogue, the dialogic form and the philosophical content follow the hermeneutic circle and complement the understanding of each other.

\section{REFERENCES}

[1] Burrell, P. S. (1916). The plot of Plato's republic. Mind, New Series, 25, 145-176.

[2] Childers, Joseph, Gary Hentzi (eds.) (1995). Columbia dictionary of modern literary \& cultural criticism. New York: Columbia University Press.

[3] Demos, R. (1937). Plato's idea of the good. The Philosophical Review, 46, 245-275.

[4] Einstein, Carl. (2004). Totality. Cambridge: MIT Press.

[5] Gadamer, Hans-Georg. (2007). Truth and method. Trans. Handing Hong. Beijing: The Commercial Press.

[6] Hu, Xiaogen. (2009). The relationship between the Platonic dialogic style and ideological system establishment. Hangzhou: Zhejiang University Press.

[7] Kidder, P. (1997). The hermeneutic and dialectic of community in development. International Journal of Social Economics, 24, 1191-1202.

[8] Michelfelder, D. P. \& R. E. Palmer (eds.) (1989). Dialogue \& deconstruction: The Gadamer-Derrida encounter. New York: State University of New York Press.

[9] Moors, K. F. (1978). Plato's use of dialogue. The Classical World, 72, 77-93.

[10] Pappas, Nickolas. (2007). Plato and The Republic. Trans. Qinghua Zhu. Guilin: Guangxi Normal University Press.

[11] Plato. The republic. (2008). Trans. Robin Waterfield. New York: Oxford University Press.

[12] Plato. The republic. (1987). Trans. D. Lee. New York: Penguin Books.

[13] Tietz, Udo. (2010). Hans-Georg Gadamer. Trans. Yi Zhu. Bejing: China Remin University Press.

[14] Zhu, Qinghua, Zhaohui Fang. (co-authors) (2005). The manifesto of the ideal state: The Republic. Kunming: Yunnan People's Publishing House.

Chunge Liu was born in Tangshan, China in 1988. She is currently a postgraduate in the School of Foreign Languages, Dalian University of Technology, China. Her major is English Language and Literature. Her research interests include philosophy of literature and hermeneutics.

Xiaodi Sui was born in Harbin, China in 1970. She received her PH.D. degree in literature from Shanghai International Studies University, China in 2010.

She is currently an associate professor in the School of Foreign Languages, Dalian University of Technology, China. Her research interests include philosophy of literature, hermeneutics and western literary theory and criticism. 